\title{
Pandemics and income inequality: a historical review
}

\author{
Adham Sayed $^{1}$ (D) Bin Peng ${ }^{1}$
}

Received: 9 November 2020 / Accepted: 24 February 2021 / Published online: 17 March 2021

(c) The Author(s), under exclusive licence to Springer Nature Switzerland AG part of Springer Nature 2021

\begin{abstract}
This paper examines the effects of pandemics on income inequality, specifically those pandemics that claimed more than 100,000 lives. Given that pandemics are events that rarely occur, we have use data spanning over the last 100 years (19152017) and relating to four pandemics. The study includes four countries that had income inequality data covering that period. Using panel data methods-fixed effects and augmented mean group estimators-we found a significant effect of these pandemics on declining income inequality. The study argues that based on the characteristics of the COVID-19 pandemic, namely that fatalities are highly concentrated in older age groups, we can neither expect a labor scarcity nor a sharp decline in productivity; however, we could expect a reduction in consumption, the possibility of savings, high unemployment rates, and high public debt ratios. The ultimate effects of COVID-19 on inequality remain unclear so far, as some of its inherent characteristics push for an increase in inequality. In contrast, others push toward a narrowing of the income gap.
\end{abstract}

Keywords Income inequality $\cdot$ Pandemic $\cdot$ COVID-19 $\cdot$ Factors model $\cdot$ Macro panel data

JEL Classification C38 $\cdot \mathrm{I} 14 \cdot \mathrm{N} 32 \cdot \mathrm{N} 34 \cdot \mathrm{O} 15$

\section{Introduction}

The number of COVID-19 related infections and deaths continues to rise, accounting, by mid-September 2020, for more than 28 million confirmed cases and around 910,000 deaths. The coronavirus is now the cause of the world's most severe recession in decades (World Bank 2020a, b). Given this reality, significant uncertainty

Adham Sayed

sadham@hust.edu.cn

Bin Peng

bpeng01@hust.edu.cn

1 School of Economics, Huazhong University of Science and Technology, Wuhan, China 
Table 1 Pandemic events with at least 100,000 deaths, 1918-2018 [Source: Jordà et al. (2020)]

\begin{tabular}{lrrr}
\hline Event & Start & End & \multicolumn{1}{l}{ Deaths } \\
\hline Spanish flu (great influenza) & 1918 & 1920 & $100,000,000$ \\
Asian flu & 1957 & 1958 & $2,000,000$ \\
Hong Kong flu & 1968 & 1969 & $1,000,000$ \\
H1N1 pandemic (2009 pandemic) & 2009 & 2009 & 203,000 \\
\hline
\end{tabular}

reigns over the eventual coronavirus outbreak effects on the world economy. Many researchers concur that deadly pandemics have detrimental effects adversely impacting economies and societies alike in both the short and medium terms (Jordà et al. 2020; McKibben and Fernando 2020).

In contrast, other researchers believe that major crises, such as wars and pandemics, entail a different impact on income distribution in any society. Piketty and Saez (2014) argue that the First and Second World Wars were behind the narrowing of income gaps in the last 150 years. Milanovic (2016) supports this conclusion underlining that pandemics reduce income inequality and constitute a force that pushes towards increased income equality. Similarly, Alfani and Murphy (2017) conclude that lower-income inequality is the expected outcome of crises with high mortality rates. Nevertheless, opinions differ on the relationship between pandemics and income distribution. Studies examining this relationship highlight that the subsequent consequences of pandemics on inequality are primarily related to the characteristics that distinguish one virus (or any other cause of a pandemic) from another.

Due to the difficulty of predicting the eventual results of the COVID-19 pandemic, just like Barro et al. (2020) and Jordà et al. (2020), we will examine the worst-case scenario. Our study extends to include pandemics whose death toll exceeded 100,000 fatalities in the last century. Thus, as adopted in Jordà et al. (2020)'s work, we will focus on pandemics (caused by a virus or bacteria) with 100,000 deaths or more. We will start with the case of the Spanish flu pandemic (Great Influenza) that spread worldwide after World War I in four successive waves lasting from 1918 until 1920 and claimed 40-100 million lives. ${ }^{1}$ We will then consider the 2009 H1N1 pandemic after looking at the Asian Flu and the Hong Kong Flu (see Table 1).

Given the challenges pertaining to the long-term availability of data, this study focuses on a few European countries in addition to the United States of America. The first panel includes four developed countries-the United States, the United Kingdom, France, and Germany_and covers the period between 1915 and 2017. The second contains 49 US states and covers the period between 1917 and 2015. We will also conduct a historical review ${ }^{2}$ of the effects of pandemics on inequality, namely the Black Death (1347-1352, also known as the Black Plague) and Great

\footnotetext{
1 There is no unified number as for the deaths resulted from this pandemic. In their study, Barro et al. (2020) estimated it at 40 million, while Jordà et al. (2020) adopt the 100 million deaths.

2 This review will focus on two historical events considered as the worst epidemiological scenarios that humankind has experienced in the past 700 years.
} 
influenza (1918-1920), based on several classical theories and modern studies, as well as historical data that until recently was absent from researchers' works. We mainly rely on Alfani's research results, who is considered one of the few researchers who studied this relationship in the long term (see Alfani 2015; Alfani and Percoco 2016; Alfani and Murphy 2017; Alfani and Ammannati 2017).

Based on Pesaran and Smith (1995) (mean group estimator, MG), and Eberhardt and Bond (2009) (augmented mean group, AMG) and to capture unobserved effects (such as economic shocks and wars) that may affect income inequality, we adopt heterogeneous interactive effects panel data models controlling for unobservable common factors. The results confirm: pandemic events with more than 100,000 deaths over the past century reduced income inequality in post-pandemic years. These results will help bridge the large gap in the literature examining the impact of pandemics on income inequality.

The rest of the paper is organized as follows: second section introduces the literature review; third section presents the data; fourth section describes the empirical model; fifth section presents the empirical results; sixth section discusses the expected impact of COVID-19 on income inequality. Final section concludes the study.

\section{Literature review}

The direct impact of the pandemic on income distribution is closely associated to the fact that the spread of a deadly virus in a society leads to the death of a large number of workers, as poverty-stricken and low-income groups are most vulnerable to disease (Furceri et al. 2020; Galletta and Giommoni 2020). For example, results from a study carried out by Schmitt-Grohé et al. (2020) in the early stages of the spread of the SARS-CoV-2 virus in the United States suggest that the relative impact of the virus was far greater on poor communities compared to affluent ones. So far, studies have concluded that the economic and health impact of COVID-19 on the most vulnerable individuals - the poor, the homeless, etc.- has been much greater than on other sections of the population (Bell et al. 2020; Adams-Prassl et al. 2020; Alon et al. 2020). Moreover, the Great Influenza (1918-1920) witnessed very high mortality rates among workers (Brainerd and Siegler 2003). Consequently, a high mortality rate among workers leads to a scarcity of labor supply, resulting in higher wages (Alfani and Murphy 2017). Similarly, a pandemic can lead to the emergence of a production crisis and a reduction in consumption, as people tend to save more, and hence this directly affects the return on capital that the rich benefit from (the top $10 \%$ income share and above). Such a pandemic effect leads, therefore, to the narrowing of the income gap.

In his study, Cipolla (1964: p 524) argued that the Black Death might have been the leading cause in the redistribution of income through the increase of wages. Based on long-term data and evidence generated by a research on real wages (Pamuk 2007; Pamuk and Shatzmiller 2014), Alfani and Murphy (2017) corroborated Cipolla's conclusion, arguing that labor scarcity led to increased real wages, narrowing the income gap. In their opinion, this was one of the direct effects of the 


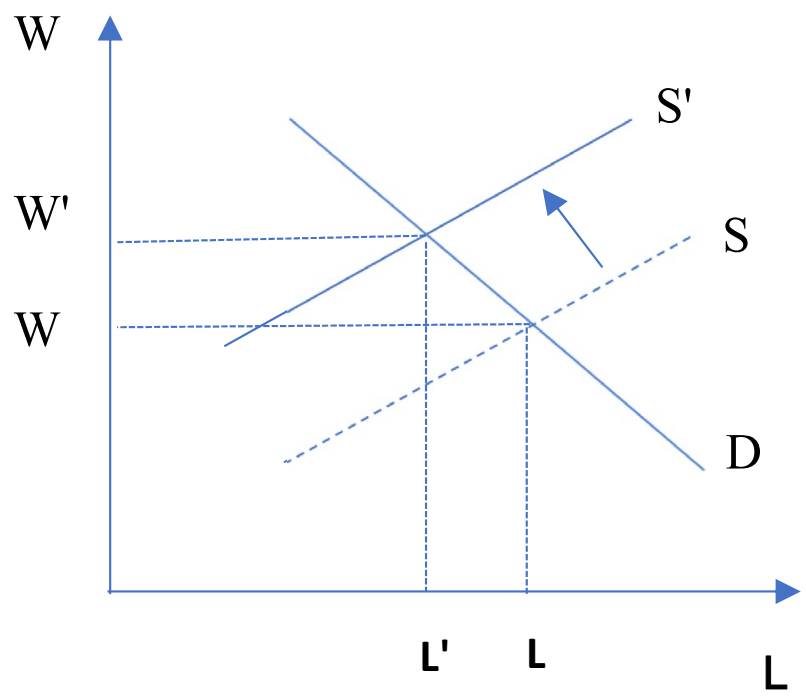

Fig. 1 The effect of the Plague on labor supply

Black Death on society. Moreover, these results refuted misconceptions on Black Death bringing about a rise in inequality (see Herlihy 1978).

The argument for the decline in inequality due to the pandemic is summarized in Fig. 1. It assumes that productivity remains constant, while the shock to the labor supply caused by the deadly pandemic (the Plague, for example) causes a decline in curve $\mathrm{S}-\mathrm{S}^{\prime}$, which leads to an increase in the wages of those workers who survive the pandemic, from $\mathrm{W}$ to $\mathrm{W}^{\prime}$. This argument proposed by Capasso and Malanima (2007) was used by $\mathrm{Li}$ and $\mathrm{Li}$ (2017) in their study of the subsequent impact of the Plague that struck families immigrating to the Manchuria region in northern China in 1910-1911. The study examined a family that arrived in a village afflicted with the Plague and another that came to a neighboring village, free of the Plague. The study found that the wages of the first family were higher than those of the second family. To explain this difference, researchers used the classical economic theory of supply and demand (see Fig. 1). For a clearer illustration, consider that two villages had the same wage level before the Plague. In the town affected by the Plague, the ensuing deaths and the delayed arrival of seasonal migrants lead to a decrease in the labor supply, thus shifting the supply curve from $S$ to $S^{\prime}$. As a result, wages in this town increase from $\mathrm{W}$ to $\mathrm{W}^{\prime}$. Meanwhile, wage levels remain unaffected in the town that is not affected by the Plague.

However, this assumption cannot be generalized to all pandemics. Productivity itself is not always stable since pandemics may lead to a decline in productivity. Alfani and Percoco (2016) argue that there is no reason to assume that every pandemic (defining the Plague) positively impacts wages because the ultimate effect depends on the magnitude of the labor supply shock relative to the productivity shock caused by the pandemic. This can be shown in Fig. 2, where the shock in productivity shifts the curve for labor demand from $\mathrm{D}$ to $\mathrm{D}^{\prime}$, leading to a decrease, 

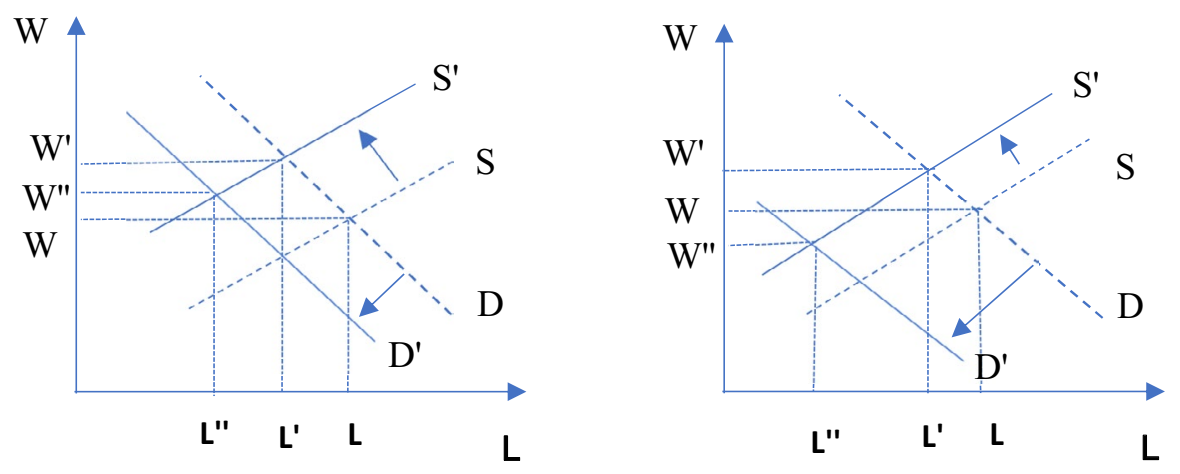

Fig. 2 The combined effect of the Plague on labor supply and productivity

stability, or a rise in wages. Therefore, if curve D falls below curve $\mathrm{S}$, we should expect the pandemic to result in higher wages. The opposite will result in lower wages.

Accordingly, the pandemic's subsequent effects on income inequality may differ according to the characteristics of the pandemic itself. Consequently, it cannot be inferred that every pandemic leads to a decrease in inequality. In this context, Alfani (2015) and Alfani and Ammannati (2017) assert that although in the very long term, inequality has always shown a tendency to rise, the Black Death was the only recorded event that led to a decrease in income inequality in northwest Italy in the period of 1300-1800, as compared to other epidemiological events that did not reduce inequality. In fact, since the seventeenth century, events with a high death toll have had entirely different effects from those of the Black Death. Based on that, Alfani (2015) concluded that the ensuing effects of different plague pandemics on inequality levels were not the same; a plague pandemic can decrease (as the effect of Black Death) or increase income inequality (e.g., the 1629-1630 Plagues).

The effects of the Black Death in Italy are similar to those of Spain. ÁlvarezNogal and De La Escosura (2013) provided historical data dating back to the year 1200 (see Fig. 3) and showing the levels of income inequality in Spain in the very long term. Based on this data, Milanovic (2016) concluded that income inequality declined due to the Black Death, and wages in northwestern Europe increased significantly because of this pandemic.

This result is confirmed in England by Clark (2007, 2010); there, the Black Death led to a decrease in the labor supply by $25-40 \%$, while real wages rose by almost $100 \%$. In parallel, this pandemic decreased the rates of return on land from $5 \%$ to around $8 \%$. As for Jordà et al. (2020), they examined the macroeconomic cost of 15 pandemics, particularly the return rates on assets, based on data dating back to the fourteenth century. Their study found that the after-effects of a pandemic can last for up to four decades, during which the natural rate of interest drops drastically $(1.5 \%)$, and in the same period, real wages rise by up to $5 \%$. The study also concludes that the real wages' response mirrors that of the natural interest rate (which also measures the return on capital). Their findings coincide with the neoclassical 


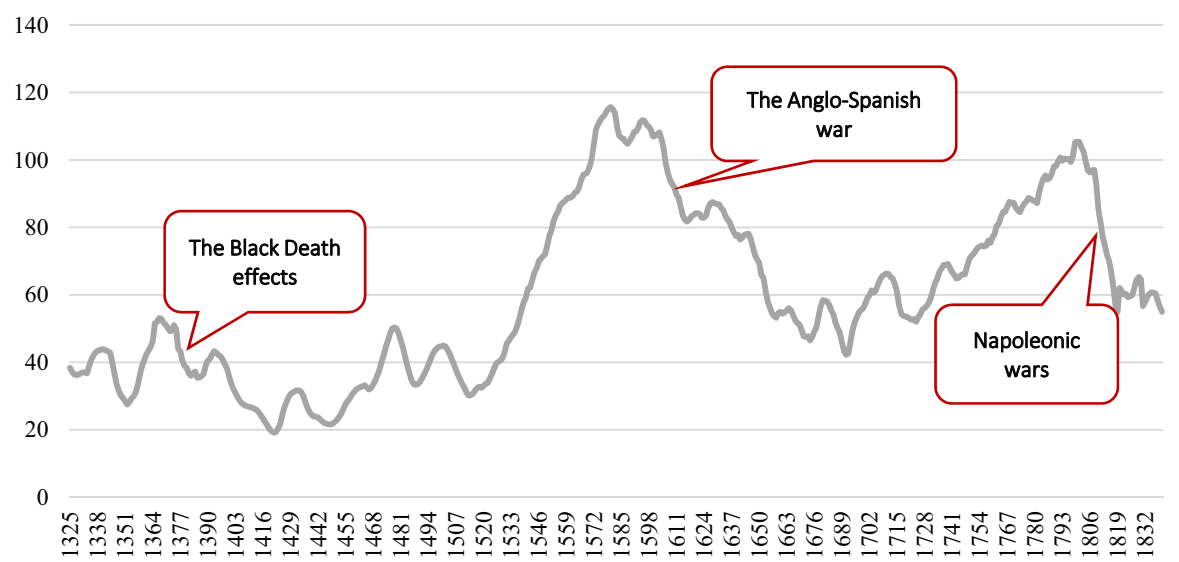

Fig. 3 Land rent-wage rate ratio in Spain (1282-1850) [Data is from Álvarez-Nogal and De La Escosura (2013). Comments on the path of inequality are from Milanovic (2016)]

model's predictions and are also consistent with historical narratives. In fact, one of the Black Death effects was labor scarcity in the European economies, which is believed to have led to the rise in real wages. In parallel, this was accompanied by lower returns on capital.

The Black Death's income effects are not much different from another grave pandemic that spread worldwide between 1918 and 1920-the Great Influenza. The results of Jordà et al. (2020), which included the Great Influenza, confirm that each pandemic with a death toll of more than 100 thousand people can positively impact reducing disparities in income. However, the 1918-1920 Flu virus, which wiped out $2 \%$ of the world's population at the time, manifested unique features and had a far greater impact on inequality than other pandemics. The age curve of mortality took a "W" shape for the Spanish flu, meaning that the number of deaths among individuals aged between 15 and 44 years was high, in contrast to the "U-shaped" mortality curve of the influenza virus (Brainerd and Siegler 2003).

In addition to this factor, Barro et al. (2020) found that the high mortality rates of the Great Influenza led to a decrease in real per capita consumption by $8 \%$, while real returns on stocks and short-term government bonds decreased drastically. Therefore, based on the modern economic theory on labor scarcity and under-consumption mentioned previously (see also Ramsey 1928; Rachel and Smith 2017; Jordà et al. 2020), it is likely that the Great Influenza contributed to a reduction in income inequality.

However, it is important to note that the literature on the impact of pandemics on inequality is still scarce, probably due to the relative scarcity of pandemics in the past 100 years. As for empirical research examining the relationship between income inequality and pandemics, Alfani (2015) and Alfani and Ammannati (2017) studied the impact of pandemics in some Italian cities during the pre-industrial era and concluded that the Black Death had a fundamental role in the decline of inequality in Italy. However, Galletta and Giommoni (2020) who studied the impact 
of the Great Influenza on inequality in Italian towns, concluded that in both short and medium terms, income inequality would increase in the towns that were most affected by the pandemic, due to the decrease in the income share held by the poor.

An additional reference for our study is that of Furceri et al. (2020), who studied the impact of five epidemics that appeared in the past 20 years (2000-2020), namely SARS 2003, H1N1 2009, MERS 2012, Ebola 2014, and Zika 2016. In contrast to other spreads, these events had a relatively weak impact on the economy and society: only a few countries were affected, and the mortality rate was moderately low compared to previous pandemics ${ }^{3}$ - the 2009 pandemic was the only exception. Furceri et al. (2020) found that these events led to a rise in inequality in the countries covered by the research. In conclusion, we believe that the characteristics of the viruses that have spread in the last two decades make it difficult to draw general conclusions about pandemics' impact on inequality.

\section{Data and variables}

To study the income inequality responses to the pandemic events during the last 100 years, we use available historical data on income inequality, measured by the top $10 \%$ income share collected from the world inequality database (WID) available at http://www.wid.world. Our sample is divided into two balanced panels; the first one comprises four developed countries: France, the USA, UK, and Germany, covering the period from 1915 to 2017. Those countries are the only countries that have a nearly complete-time series since 1915 . For all other countries, the time series is significantly shorter and mostly start in 1980. This limitation is the same for the Gini index. The second panel includes 49 states of the United States of America from 1915 to 2015.

For the pandemic events, following Jordà et al. (2020), we focused on four events (see Table 1). We constructed a dummy variable for a pandemic, which takes the value 1 when the number of deaths caused by the pandemic is more than 100,000, and 0 otherwise.

For the robustness check, we used two control variables. The first one is the level of economic growth measured by GDP per capita (GDPPC) in 2011 US\$, 2011 benchmark, derived from two sources. Between 1915 and 1959, the data were collected from the Maddison Project Database, 2018 version (available at http://www. ggdc.net/maddison), while the rest was collected from the World Bank Database. The second control variable was the population (POP) derived from the Maddison Project Database, 2018 version, and the World Bank Database.

The data in Fig. 1 was sourced from Álvarez-Nogal and De La Escosura (2013). Table A1 in the Appendix illustrates descriptive statistics for the variables.

\footnotetext{
${ }^{3}$ Based on Ma et al. (2020), the global deaths caused by these pandemics and the number of countries affected by the virus are, respectively: SARS (774 deaths; 29 countries), H1N1 (284,000 deaths; 201 countries), MERS (498 deaths; 26 countries), Ebola (11,323 deaths; 10 countries), and Zika (20 deaths; 50 countries).
} 


\section{Empirical model}

To estimate pandemics' impact on income inequality, we followed the methods proposed by Pesaran (2006) and Eberhardt and Bond (2009). Models 1 and 2 give our econometrics representation of the income inequality responses to the pandemic events. The first model is a Fixed effects model, with intercept and slope coefficients that vary across countries:

$$
y_{i t}=\alpha_{i}+\delta_{i} t+\beta_{i} \mathrm{PAN}_{i t}+\aleph_{i} x_{i t}+u_{i t}, i=1,2, \ldots, N ; t=1,2, \ldots, T,
$$

where $y_{i t}$ are a vector of dependent variables includes the top $10 \%$ share pre-tax national income $\left(\mathrm{INQ}_{i t}\right)$ and its first difference $\left(\Delta \mathrm{INQ}_{i t}\right)$, for country $i$ at time $t$; $\mathrm{PAN}_{i t}$ is a dummy variable indicating a pandemic event that affects country $i$ in year $t ; x_{i t}$ is a vector that includes two lags of the pandemic dummy and the independent variable. In the baseline, as for Barro et al. (2020) and Furceri et al. (2020), we do not control for other factors affecting inequality; then, the regressions do not include any independent variables. That is, our focus is on disaster pandemics, which are treated as exogenous shocks. $\beta$ and $\aleph$ are parameters to be estimated; $\beta$ is our main parameter of interest, which describes the change in income inequality as a response to a pandemic. If the estimated coefficient $\beta$ is negative, pandemic reduces income inequality; otherwise, it will increase. $\alpha_{i}$ is a country-specific effect; $\delta_{i} t$ is a countryspecific time trend; and $u_{i t}$ is the error term which can be both serially and cross sectionally correlated.

Recent literature argues that the history of income distribution has been political in-depth and has had a strong correlation with the political and financial policies, globalization, war and pandemics, and other unknown common shocks; see Acemoglu and Robinson (2002), Piketty and Saez (2003, 2014), Milanovic (2016), Alfani (2015), and Alvaredo et al. (2018). It further leads to the presence of crosssectional dependence. Ignorance of common global shocks may lead to inconsistent and biased estimates (Ditzen 2018). Therefore, we adopted heterogeneous interactive effects panel data models controlling for unobservable common factors.

To account for all the unobserved cofounders, we used an interactive effects panel data model introduced by Pesaran (2006). Then we considered a model with an unobserved common factor and a heterogeneous factor loading, represented as:

$$
\mathrm{INQ}_{i t}=\alpha_{i}+\delta_{i} t+\beta_{i} \mathrm{PAN}_{i t}+\aleph_{i} x_{i t}+\gamma_{i} f_{t}+e_{i t}, i=1,2, \ldots, N ; t=1,2, \ldots, T,
$$

where, $f_{t}$ is a $(m \times 1)$ vector of unobserved common effects, where $\mathrm{m}$ is the number of unobserved factors; $\gamma_{i}$ is a heterogeneous factor loading, and $e_{i t}$ is a cross-section country-specific IID error term. $f_{t}, \gamma_{i}$ and $e_{i t}$ are all unobserved. In this case, common factors are possibly non-stationary and are maybe correlated with the regressors. $e_{i t}$ is allowed to be serially correlated over $\mathrm{t}$ and weakly correlated across $i$ (Chudik et al. 2011).

Eberhardt and Bond (2009) proposed an augmented mean group (AMG) estimate for macro panel data that allows for slope heterogeneity, non-stationarity, and accounts for cross-sectional dependence through the inclusion of a "common dynamic effect" in the country regression, which is extracted from the year dummy 
Table 2 Cross-sectional dependence tests results

\begin{tabular}{|c|c|c|c|c|}
\hline \multirow[t]{2}{*}{ Tests } & \multicolumn{2}{|c|}{ Panel 1 (4 countries) } & \multicolumn{2}{|c|}{ Panel 2 (49 states) } \\
\hline & Statistics & $P$ values & Statistics & $\begin{array}{l}P \\
\text { val- } \\
\text { ues }\end{array}$ \\
\hline $\mathrm{LM}_{\mathrm{BP}}$ test & 359.4 & 0.000 & $6.20 \mathrm{E}+04$ & 0.000 \\
\hline $\mathrm{LM}_{\mathrm{adj}}$ test & 580.3 & 0.000 & 6981 & 0.000 \\
\hline $\mathrm{LM}_{\mathrm{CD}}$ test & 18.86 & 0.000 & 241.1 & 0.000 \\
\hline
\end{tabular}

Note: if $T$ (time dimension) is larger than $N$ (cross-sectional dimension), we may use for these purposes the Breusch and Pagan's (1980) Lagrange multiplier (LM) test $\left(\mathrm{LM}_{\mathrm{BP}}\right)$. But if $N$ is larger than $T$, we may use for these purposes the Pesaran's (2004) CD test $\left(\mathrm{LM}_{\mathrm{CD}}\right)$

\begin{tabular}{llllll}
\hline Variables & Panel 1 & & & Panel 2 & \\
\cline { 2 - 3 } \cline { 5 - 6 } & Value & $P$ values & & Value & $\begin{array}{l}P \\
\text { values }\end{array}$ \\
\hline INQ & -0.3688 & 0.3561 & & 0.2324 & 0.4081 \\
$\Delta$ INQ & -3.8451 & 0.0001 & & -27.4413 & 0.000 \\
\hline
\end{tabular}

Note: the null hypothesis is the presence of unit root in panel data with cross-sectional dependence in the form of common factor dependence
Table 3 Im-Pesaran-Shin (CIPS) panel unit root test results

\section{Empirical results}

Before we modeled the cross-sectional dependence, we checked its existence. We considered $\mathrm{LM}_{\mathrm{BP}}, \mathrm{LM}_{\mathrm{adj}}$, and $\mathrm{LM}_{\mathrm{CD}}$ tests proposed by Breusch and Pagan (1980), Pesaran et al. (2008), and Pesaran (2004), respectively. Table 2 shows the results of the cross-sectional dependence tests. We rejected the null hypothesis of no crosssectional dependence for both panels.

Due to the existence of cross-sectional dependence, the Im-Pesaran-Shim panel unit-root test (CIPS) proposed by Pesaran (2007) was used to check the stationarity of the series. Table 3 reports the results and shows that both panels fail to reject the null hypothesis; therefore, all variables are non-stationary. 
Table 4 Kao panel co-integration tests results

\begin{tabular}{|c|c|c|c|c|}
\hline & \multicolumn{2}{|l|}{ Panel 1} & \multicolumn{2}{|l|}{ Panel 2} \\
\hline & Statistic & $P$ value & Statistic & $P$ value \\
\hline Modified dickey-fuller $t$ & -26.3196 & 0.000 & -7.1831 & 0.000 \\
\hline Dickey-fuller $t$ & -16.9713 & 0.000 & -6.1137 & 0.000 \\
\hline Augmented dickey-fuller $t$ & -10.8971 & 0.000 & -2.9823 & 0.0014 \\
\hline Unadjusted modified dickey fuller $t$ & -62.9571 & 0.000 & -25.1922 & 0.000 \\
\hline Unadjusted dickey-fuller $t$ & -20.4795 & 0.000 & -12.1549 & 0.000 \\
\hline
\end{tabular}

Table 5 Panel data estimates for determinants of income inequality (panel 1)

\begin{tabular}{|c|c|c|c|c|}
\hline \multirow{2}{*}{$\begin{array}{l}\text { Independent vari- } \\
\text { ables }\end{array}$} & \multicolumn{2}{|l|}{ INQ } & \multicolumn{2}{|l|}{$\Delta \mathrm{INQ}$} \\
\hline & $\mathrm{FE}$ & AMG & $\mathrm{FE}$ & AMG \\
\hline PAN & $\begin{array}{c}-0.0048 * * \\
(-2.08)\end{array}$ & $\begin{array}{r}-0.08138 * \\
(-20.73)\end{array}$ & $\begin{array}{c}-0.00538 * * \\
(-2.27)\end{array}$ & $\begin{array}{r}-0.05203 * \\
(-14.06)\end{array}$ \\
\hline $\mathrm{PAN}_{i, t-1}$ & $0.00304(1.16)$ & $\begin{array}{r}-0.03012 * \\
(-14.19)\end{array}$ & 0.002987 (1.12) & $\begin{array}{c}-0.026976^{*} \\
(-12.96)\end{array}$ \\
\hline $\mathrm{PAN}_{i, t-2}$ & $0.0016(0.7)$ & $-0.0137 *(-8.88)$ & $0.00115(0.48)$ & $\begin{array}{r}-0.04024 * \\
(-30.77)\end{array}$ \\
\hline $\mathrm{INQ}_{i, t-1}$ & $1.1539 *(23.7)$ & $0.536096^{*}(8.9)$ & - & - \\
\hline $\mathrm{INQ}_{i, t-2}$ & $-0.1961^{*}(-4.03)$ & $\begin{array}{c}-0.28109 * * \\
(-2.12)\end{array}$ & - & - \\
\hline$\Delta \mathrm{INQ}_{i, t-1}$ & - & - & $0.186997 *(3.74)$ & $-0.16401 *(-3.49)$ \\
\hline$\Delta \mathrm{INQ}_{i, t-2}$ & - & - & $-0.05557(-1.12)$ & $-0.21049 *(-3.42)$ \\
\hline Constant & $0.0152 *(3.41)$ & $0.3295 *(8.66)$ & $5.02 \mathrm{E}-05(0.07)$ & $0.052921 *(77.78)$ \\
\hline n. obs & 410 & 410 & 409 & 409 \\
\hline
\end{tabular}

$t$ Statistics in parentheses. FE and AMG are fixed effects and augmented mean group estimators (respectively)

*Significant at 0.01 level; **at 0.05 level; ***at 0.10 level

Since the variables are non-stationary, we needed to test for co-integration. Table 4 reports the results of the Kao (1999) panel co-integration tests. These tests can accommodate serially correlated error terms, country-specific intercepts, and trends. For all tests, the results indicated the rejection of the null hypothesis of no co-integration.

After we verified the presence of co-integration in our model, Tables 5 and 7 show results from the estimation of panels 1 and 2 (respectively) with fixed effects (FE) and augmented mean group (AMG) estimators.

Table 5 reports the results for panel 1 with INQ as the dependent variable in the first and second columns, whereas those with $\triangle$ INQ as the dependent variable are in the next two columns. We found that estimated coefficients of the dummy variables representing the pandemics events (PAN) are all significantly negative, at least at the 5\% level, indicating that pandemics with more than 100,000 deaths 
Table 6 Panel data estimates with control variables

\begin{tabular}{|c|c|c|c|c|}
\hline \multirow{2}{*}{$\begin{array}{l}\text { Independent vari- } \\
\text { ables }\end{array}$} & \multicolumn{2}{|l|}{ INQ } & \multicolumn{2}{|l|}{$\Delta \mathrm{INQ}$} \\
\hline & $\mathrm{FE}$ & AMG & $\mathrm{FE}$ & AMG \\
\hline PAN & $\begin{array}{c}-0.0048 * * \\
(-2.06)\end{array}$ & $-0.134 *(-33.91)$ & $\begin{array}{c}-0.00533 * * \\
(-2.25)\end{array}$ & $-0.1231 *(-36.69)$ \\
\hline PAN $_{i, t-1}$ & $0.00303(1.16)$ & $-0.074 *(-34.88)$ & $0.00296(1.11)$ & $-0.1276^{*}(-61.04)$ \\
\hline $\mathrm{PAN}_{i, t-2}$ & $0.0016(0.7)$ & $-0.072 *(-29.27)$ & $0.00114(0.48)$ & $-0.0839 *(-69.01)$ \\
\hline $\mathrm{INQ}_{i, t-1}$ & $1.1496 *(23.54)$ & $0.4606 *(7.05)$ & - & - \\
\hline $\mathrm{INQ}_{i, t-2}$ & $0.1917 *(-3.93)$ & $-0.3329 *(-2.76)$ & - & - \\
\hline$\Delta \mathrm{INQ}_{i, t-1}$ & - & - & $0.18261^{*}(3.65)$ & $-0.1542 *(-2.82)$ \\
\hline$\Delta \mathrm{INQ}_{i, t-2}$ & - & - & $-0.0595(-1.2)$ & $-0.1818 *(-2.62)$ \\
\hline GDPPC & $3.67 \mathrm{E}-08(0.53)$ & $\begin{array}{l}-1.88 \mathrm{E}-06 \\
(-0.7)\end{array}$ & $5.85 \mathrm{E}-08(0.83)$ & $7.84 \mathrm{E}-07 *(3.73)$ \\
\hline POP & $1.11 \mathrm{E}-08(0.45)$ & $3.48 \mathrm{E}-06(1.43)$ & $4.54 \mathrm{E}-09(0.18)$ & $1.35 \mathrm{E}-06^{*}(3.24)$ \\
\hline Constant & $0.0133 *(2.84)$ & $0.208 *(2.44)$ & $-0.0016(-0.89)$ & $-0.01843(-1.25)$ \\
\hline n. obs & 410 & 410 & 409 & 409 \\
\hline
\end{tabular}

$t$ Statistics in parentheses. FE and AMG are fixed effects and augmented mean group estimators (respectively)

*Significant at 0.01 level; **at 0.05 level; ***at 0.10 level

lead to a significant decrease in income inequality. Then, the pandemics in the last 100 years are estimated to have reduced income inequality by about $8 \%$ and $5 \%$ when we controlled for the unobserved common shocks (using AMG estimator for both INQ and $\triangle \mathrm{INQ}$, respectively), and about $0.5 \%$ using FE estimator for both INQ and $\triangle \mathrm{INQ}$.

For lag variables, using FE, the estimated coefficient on the first and second pandemics lag variables are positive but insignificant. In contrast, using AMG, both first and second lag variables are significantly negative, indicating that the redistributive effects of pandemics on income inequality tend to last for some time.

This finding is consistent with results regarding the post-pandemic effect on inequality distribution, real wages, and return on capital, such as those reported in Clark (2007, 2010), Jordà et al. (2020), Alfani and Murphy (2017), and Li and Li (2017). For a panel of countries, these studies found that pandemic with unique characteristics (e.g., Hight death rate) lead to a decline in income inequality. Furthermore, our findings are contrary to the results obtained from other studies, which tend to show that pandemics increase the income gap [e.g., Furceri et al. (2020), and Galletta and Giommoni (2020)].

We carried out a robustness check of these findings by including two control variables in the regression - real GDP per capita and population — and we repeated the regression using the same estimation methods. The results are reported in Table 6, and the estimated parameters for pandemic events (PAN) are close to those in Table 5, showing that pandemics lead to a reduction in income inequality. The only difference is that using AMG, the results show that pandemics' impact is negatively highest when we control for economic growth and population (pandemics reduce inequality by around $12 \%$ ). 
Table 7 Panel data estimates for determinants of income inequality (panel 2)

\begin{tabular}{|c|c|c|c|c|}
\hline \multirow{2}{*}{$\begin{array}{l}\text { Independent vari- } \\
\text { ables }\end{array}$} & \multicolumn{2}{|l|}{ INQ } & \multicolumn{2}{|l|}{$\Delta \mathrm{INQ}$} \\
\hline & $\mathrm{FE}$ & AMG & $\mathrm{FE}$ & AMG \\
\hline PAN & $\begin{array}{c}-0.00659 * \\
(-3.63)\end{array}$ & $\begin{array}{r}-0.10838 * \\
(-63.78)\end{array}$ & $\begin{array}{c}-0.00834^{*} \\
(-4.45)\end{array}$ & $-0.0845^{*}(-55.06)$ \\
\hline $\mathrm{PAN}_{i, t-1}$ & $0.00625^{*}(3.11)$ & $0.072629 *(78.02)$ & $0.006316 *(3.04)$ & $0.0853 *(86.46)$ \\
\hline $\mathrm{PAN}_{i, t-2}$ & $0.00343 * *(1.91)$ & $\begin{array}{r}-0.15851^{*} \\
(-114.2)\end{array}$ & $0.004329 *(2.34)$ & $0.00558 *(6.31)$ \\
\hline $\mathrm{INQ}_{i, t-1}$ & $0.772279 *(53.28)$ & $0.06254(1.5)$ & - & - \\
\hline $\mathrm{INQ}_{i, t-2}$ & $0.07459 *(5.15)$ & $-0.17061 *(-7.7)$ & - & - \\
\hline$\Delta \mathrm{INQ}_{i, t-1}$ & - & - & $\begin{array}{r}-0.16787 * \\
(-11.58)\end{array}$ & $-0.4896^{*}(-18.85)$ \\
\hline$\Delta \mathrm{INQ}_{i, t-2}$ & - & - & $\begin{array}{c}-0.11128 * \\
(-7.67)\end{array}$ & $-0.2287^{*}(-12.04)$ \\
\hline Constant & $0.0572 *(18.31)$ & $0.4363 *(29.38)$ & $-0.0002(-0.37)$ & $-0.0874 *(-329.5)$ \\
\hline n. obs & 4849 & 4849 & 4848 & 4848 \\
\hline
\end{tabular}

$t$ Statistics in parentheses. FE and AMG are fixed effects and augmented mean group estimators (respectively)

*Significant at 0.01 level; **at 0.05 level; ***at 0.10 level

Table 7 repeats the analysis for 49 states of the United States of America (panel 2 ). The sample size is bigger than that of panel 1. The main results are similar to those of panel 1 (see Table 5), although the estimated effects on income inequality are more extensive in magnitude.

\section{What is the expected impact of COVID-19 on income inequality?}

The previous parts offered the presentation of a worst-case scenario caused by a pandemic. By comparison, the COVID-19 pandemic presents certain characteristics that distinguish it from previous pandemics. In what follows, we will discuss some of the most important factors that may control the eventual impact of the current outbreak on income inequality.

\section{Mortality rates}

The SARS-CoV-2 virus is considered one of the most dangerous viruses to infect the respiratory system since the beginning of the last century, specifically since the Great Influenza (Ferguson et al. 2020). McKibben and Fernando (2020) used the same model ${ }^{4}$ as McKibbin and Sidorenko (2006) to explore seven different

\footnotetext{
${ }^{4}$ Uses a modelling technique to explore four different pandemic influenza scenarios: "mild" scenario in which the pandemic is similar to the 1968-69 Hong Kong Flu; "moderate" scenario which is similar to the Asian flu of 1957; "severe" scenario based on the Great Influenza of 1918-19 (lower estimate of the case fatality rate), and an "ultra" scenario similar to Great Influenza but with upper-middle estimates of the case fatality rate.
} 
scenarios of how COVID-19 might evolve in the coming year. They found that the death toll estimates range between 15 and 68 million deaths for the lowest and highest pandemic scenarios, respectively. However, more than 9 months following the emergence of the COVID-19 pandemic and given the medical advancement and health measures taken to control the spread, the death toll of COVID-19 is no more expected to reach the levels of the Great Influenza. In fact, according to Barro et al. (2020), the Great Influenza led to the death of $2 \%$ of the world's population at that time-in today's numbers, that is equivalent to 150 million people. Beyond the projected death toll, the highest mortality rates are so far concentrated in the seniors' age group - that is 65 years of age and above. Thus, a direct impact on the labor supply is not expected.

\section{Pandemics and the economy: from the "Great Depression" to the "Great Lockdown"}

The rapid and severe shock of the COVID-19 pandemic and the lockdown measures taken to contain it plunged the global economy into the worst recession since World War II. According to World Bank projections, the US economy will contract by $6.1 \%$, while the Euro area is expected to contract by $9.1 \%$ in 2020 . The average per capita income is also expected to decrease by $3.6 \%$, causing millions of people to fall into extreme poverty. Other scenarios predict further deteriorating conditions where global GDP may fall by up to $8 \%$ this year (World Bank 2020a). The International Monetary Fund has called this unprecedented crisis "The Great Lockdown" and classified it as the worst recession since the years of the "Great Depression" and much worse than the global financial crisis of 2008-2009, especially that it has resulted from a pandemic which is a first. The cumulative loss in global GDP due to this crisis is expected to be about 12 trillion US dollars over 2020 and 2021 (IMF 2020a).

In this context, McKibben and Fernando (2020) explored the losses that can be incurred by the GDP in the global economy. According to the adopted scenarios, the study expected losses of around 2.4 trillion US dollars based on a low-end pandemic pattern. As for the worst-case scenario, similar to the Great Influenza, the global GDP is expected to drop by about 9 trillion US dollars during the first year of the pandemic. This number remains lower than the 12 trillion US dollars predicted by the IMF. Therefore, this pandemic is expected to have one of the worst economic repercussions ever. Even under such pessimistic outlooks at the beginning of the virus' spread, the results were far more disastrous.

The present pandemic has led to a significant decline in consumption, as isolation measures pushed people to reduce their consumption to the lowest level and opt for more precautionary savings (World Bank 2020b), which will have a negative impact on returns on capital (Barro et al. 2020; Jordà et al. 2020). Furthermore, the total closure of countries contributed to a complete or partial halt in productivity, leading to a further decline in the returns on capital, all of which will reduce inequality. However, the impact on productivity may also lead to an increase in unemployment figures. According to ILO (2020b) estimates, about $40 \%$ of the global workforce 
are employed in sectors facing a high risk of worker displacement, ${ }^{5}$ thus forecasting severe adverse effects on income.

\section{Public debt levels}

The COVID-19 pandemic has led to a number of unprecedented financial interventions by governments aiming to limit the adverse consequences of the pandemic; this has contributed to a significant increase in public debt-to-GDP ratios (IMF 2020b). As several studies indicate, public debt leads to an increase in income inequality, for countries work to borrow from those who own wealth to pay off the debt and its interests. In such cases, countries intend to impose new taxes, mostly targeting people with low income, leading to an inverted redistribution of income, from the poorest to the richest (Piketty 2014; You and Dutt 1996). However, the ultimate consequences of debt depend on the measures taken by governments to repay this debt. In previous crises such as World War II, many countries imposed exceptional taxes on the rich to cover the cost of the war, which was a contributing factor in reducing inequality (Piketty and Zucman 2014; Milanovic 2016). In other events, such as the 2008 financial crisis, governments did not adopt the same approach, which led to an increase in inequality.

Based on the characteristics of the COVID-19 pandemic, namely that fatalities are highly concentrated in older age groups, we can neither expect a labor scarcity nor a sharp decline in productivity. But we could expect a reduction in consumption, a probable increase in savings, high unemployment rates, and high public debt ratios. The ultimate effects of COVID-19 on inequality remain thus unclear for now, as some of its inherent characteristics push for an increase in inequality. In contrast, others push toward a narrowing of the income gap.

\section{Conclusion}

The COVID-19 pandemic has caused a massive economic crisis described as the worst in decades and whose effects are even worse than those of the 2008 financial crisis. This pandemic has revealed high levels of economic, health, and social inequality that afflict almost all societies. Although the final effects of this pandemic cannot be foreseen yet, there is no doubt that it will have significant impacts on income inequality.

Accordingly, this paper based its analysis on the past experiences to examine the impact of past pandemics on income inequality, relying on the definition provided by Jordà et al. (2020) of a pandemic; a pandemic is a health crisis (virus or bacteria) that leads to more than a hundred thousand deaths. The study period covered four pandemics that occurred between 1915 and 2017.

\footnotetext{
5 An estimated 155 million full-time jobs were lost during the first quarter of 2020, and it is estimated to reach 400 million for the second quarter (ILO 2020a).
} 
This study provided new evidence that the pandemics that occurred over the last 100 years contributed to a decline in income inequality in the years following the pandemics. These results also contributed to filling the void left by the lack of research in this field. The study argued that the final effects of the pandemic on income inequality are mainly related to the characteristics of the pandemic, especially in terms of its impact on labor supply, productivity and consumption, and public debt.

Based on these results, the final effects of the COVID-19 pandemic on income inequality remain unclear as this pandemic has characteristics that differentiate it from previous scenarios. Future research may help us extract the ultimate and final effects of the SARS-COV-2 virus on income inequality. Lastly, it is important to emphasize that governments can play a more significant role in containing the catastrophic effects of this pandemic by supporting the most affected vulnerable groups. That would contribute to mitigating the negative effects of the pandemic on income distribution.

Supplementary Information The online version contains supplementary material available at https://doi. org/10.1007/s43546-021-00059-4.

\section{Declarations}

Conflict of interest None declared.

Data availability All data analysed are included in the paper.

\section{References}

Acemoglu D, Robinson JA (2002) The political economy of the kuznets curve. Rev Dev Econ 6(2):183203. https://doi.org/10.1111/1467-9361.00149

Adams-Prassl A, Boneva T, Golin M, Rauh C (2020) Inequality in the impact of the coronavirus shock: evidence from real time surveys. J Public Econ 189:104245. https://doi.org/10.1016/j.jpube co. 2020.104245

Alfani G (2015) Economic inequality in northwestern Italy: a long-term view (fourteenth to eighteenth centuries). J Econ Hist 75(4):1058-1096. https://doi.org/10.1017/S0022050715001539

Alfani G, Ammannati F (2017) Long-term trends in economic inequality: the case of the Florentine state, c. 1300-1800. Econ Hist Rev 4(2017):1072-1102. https://doi.org/10.1111/ehr.12471

Alfani G, Murphy TE (2017) Plague and lethal epidemics in the pre-industrial world. J Econ Hist 77(1):314-343. https://doi.org/10.1017/S0022050717000092

Alfani G, Percoco M (2016) Plague and long-term development: the lasting effects of the 1629-30 epidemic on the Italian cities. In: EHES working paper no. 106. https://doi.org/10.1111/ehr.12652

Alon T, Doepke M, Olmstead-Rumsey J, Tertilt M (2020) The impact of Covid-19 on gender equality. In: NBER working paper no. 26947. https://doi.org/10.1017/CBO9781107415324.004

Alvaredo F, Chancel L, Piketty T, Saez E, Zucman G (2018) The elephant curve of global inequality and growth. AEA Pap Proc 108:103-108. https://doi.org/10.1257/pandp.20181073

Álvarez-Nogal C, Prados De La Escosura L (2013) The rise and fall of Spain (1270-1850). Econ Hist Rev 66(1):1-37. https://doi.org/10.1111/j.1468-0289.2012.00656.x

Barro RJ, Ursúa JF, Weng J (2020) The coronavirus and the great influenza pandemic: lessons from the "Spanish Flu" for the coronavirus's potential effects on mortality and economic activity. In: NBER working paper series no. 26866 
Bell B, Bloom N, Blundell J, Pistaferri L (2020) Prepare for large wage cuts if you are younger and work in a small firm. VoxEU.Org. https://voxeu.org/article/prepare-large-wage-cuts-if-you-are-youngerand-work-small-firm

Brainerd E, Siegler M (2003) The economic effects of the 1918 influenza pandemic. In: CEPR discussion paper no. 3791. http://www.papers3://publication/uuid/2F96A383-9DF1-40BF-86D4-B41B1766EC OB

Breusch TS, Pagan AR (1980) The Lagrange multiplier test and its applications to model specification in econometrics. Rev Econ Stud 47(1):239-253

Capasso S, Malanima P (2007) Economy and population in Italy: 1300-1900. Popolazione E Storia $8(2): 15-40$

Chudik A, Pesaran MH, Tosetti E (2011) Weak and strong cross-section dependence and estimation of large panels. Econom J 14(1):45-90. https://doi.org/10.1111/j.1368-423X.2010.00330.x

Cipolla CM (1964) Economic depression of the renaissance? Econ Hist Rev 16(3):519-524. https://doi. org/10.1111/j.1468-0289.1964.tb01745.x

Clark BG (2007) The long march of history: farm wages, population, and economic growth, England 1209-1869. Econ Hist Rev 60(1):97-135

Clark G (2010) The macroeconomic aggregates for England, 1209-2008. In: Research in economic history, vol 27. Elsevier. https://doi.org/10.1108/s0363-3268(2010)0000027004

Ditzen J (2018) Estimating dynamic common-correlated effects in Stata. Stata J 18(3):585-617. https:// doi.org/10.1177/1536867x1801800306

Eberhardt M, Bond S (2009) Cross-section dependence in non-stationary panel models: a novel estimator. In: Munich Personal RePEc Archive (MPRA) paper no. 17692

Ferguson NM, Laydon D, Nedjati-Gilani G, Imai N, Ainslie K, Baguelin M, Bhatia S, Boonyasiri A, Cucunubá Z, Cuomo-Dannenburg G, Dighe A, Dorigatti I, Fu H, Gaythorpe K, Green W, Hamlet A, Hinsley W, Okell LC, Van Elsland S et al (2020) Report 9 - impact of non-pharmaceutical interventions (NPIs) to reduce COVID-19 mortality and healthcare demand. In: Imperial college COVID-19 response team. https://doi.org/10.25561/77482

Furceri D, Loungani P, Ostry JD, Pizzuto P (2020) Will Covid-19 affect inequality? Evidence from past pandemics. Covid Econ (12):138-157. https://static1.squarespace.com/static/57d002e01b631bc 215df193b/t/5ea03f85faa41572500e7a69/1587560340109/CovidEconomics8.pdf\#page=75

Galletta S, Giommoni T (2020) the effect of the 1918 influenza pandemic on income inequality: evidence from Italy. In: CEPR discussion papers 3791, C.E.P.R. discussion papers. https://doi.org/10.2139/ ssrn.3634793

Herlihy D (1978) The distribution of wealth in a renaissance community: Florence 1427. In: In towns in societies: essays in economic history and historical sociology, edited by Philip Abrams and Edward Anthony Wrigley, pp 131-157

ILO (2020a) COVID-19 and the world of work.Fifth edition. In: International Labour Organization (Issue June)

ILO (2020b) ILO monitor 2nd edition: COVID-19 and the world of work. In: International Labour Organization (Issue April). https://doi.org/10.18356/ba5cc386-en

IMF (2020a) A crisis like no other, an uncertain recovery. In: World Economic Outlook Update, June.

IMF (2020b) World economic outlook: the great lockdown. In: International Monetary Fund (Issue April)

Jordà Ò, Singh SR, Taylor AM (2020) Longer-run economic consequences of pandemics. In: NBER working paper no. 26934. https://doi.org/10.1017/CBO9781107415324.004

Kao C (1999) Spurious regression and residual-based tests for co-integration in panel data. J Econom 90(1):1-44. https://doi.org/10.1016/S0304-4076(98)00023-2

Li D, Li N (2017) Moving to the right place at the right time: economic effects on migrants of the manchuria plague of 1910-11. Explor Econ Hist 63:91-106. https://doi.org/10.1016/j.eeh.2016.11.001

Ma C, Rogers J, Zhou S (2020) Global financial effects. Covid Econ 5:56-78

McKibben W, Fernando R (2020) The global macroeconomic impacts of COVID-19: seven scenarios. In: CAMA working paper 19/2020. https://cama.crawford.anu.edu.au/sites/default/files/publication/ cama_crawford_anu_edu_au/2020-03/19_2020_mckibbin_fernando_0.pdf

McKibbin WJ, Sidorenko AA (2006) Global macroeconomic consequences of pandemic influenza. In: CAMA working papers 2006-26, Centre for Applied Macroeconomic Analysis, Crawford School of Public Policy, The Australian National University

Milanovic B (2016) Income inequality is cyclical. Nature. https://doi.org/10.1038/537479a

Pamuk Ş (2007) The Black Death and the origins of the 'Great Divergence' across Europe, 1300-1600. Eur Rev Econ Hist 11(3):289-317. https://doi.org/10.1017/S1361491607002031 
Pamuk Ş, Shatzmiller M (2014) Plagues, wages, and economic change in the Islamic Middle East, 7001500. J Econ Hist 74(1):196-229. https://doi.org/10.1017/S0022050714000072

Pesaran MH (2004) General diagnostic tests for cross section dependence in panels. In: CESifo working paper no. 1233. https://doi.org/10.1103/PhysRevB.85.241102

Pesaran MH (2006) Estimation and inference in large heterogeneous panels with a multifactor error structure. Econometrica 74(4):967-1012

Pesaran MH (2007) A simple panel unit root test in the presence of cross-section dependence. J Appl Econom 22:265-312. https://doi.org/10.1002/jae.951

Pesaran MH, Smith R (1995) Estimating long-run relationships from dynamic. J Econom 68:79-113

Pesaran MH, Ullah A, Yamagata T (2008) A bias-adjusted LM test of error cross-section independence. Econom J 11(1):105-127. https://doi.org/10.1111/j.1368-423X.2007.00227.x

Piketty T (2014) Capital in the twenty-first century. Harvard University Press. https://doi.org/10.1017/ CBO9781107415324.004

Piketty T, Saez E (2003) Income inequality in the United States, 1913-1998. Q J Econ CXVII I(1):1-39. https://doi.org/10.1162/00335530360535135

Piketty T, Saez E (2014) Inequality in the long run. Science 344(6186):838-843

Piketty T, Zucman G (2014) Capital is back: wealth-income ratios in rich countries 1700-2010. Q J Econ 129(3):1255-1310. https://doi.org/10.1093/qje/qju018.Advance

Rachel L, Smith TD (2017) Are low real interest rates here to stay? Int J Cent Bank 13(3):1-42

Ramsey FP (1928) A mathematical theory of saving. Econ J 38(152):543-559. https://doi. org/10.4324/9781315199818-8

Schmitt-Grohé S, Teoh K, Uribe M (2020) Covid-19: testing inequality in New York City. In: NBER working paper no. 27019. https://doi.org/10.3386/w27019

World Bank (2020a) Global economic prospects. (Issue June). https://doi.org/10.1596/978-1-4648-1553-9

World Bank (2020b) Projected poverty impacts of COVID-19 (coronavirus). (Vol. June). http://pubdo cs.worldbank.org/en/461601591649316722/Projected-poverty-impacts-of-COVID-19.pdf

You J, Dutt AK (1996) Government debt, income distribution and growth. Camb J Econ 20:335-351 